\title{
Enhancing the Students' Rhetoric Attainments in Teaching of College English Intensive Reading
}

\author{
ZHANG Rong-gen \\ Shanghai Publishing and Printing College, Shanghai, China
}

\begin{abstract}
Beginning with various definitions of rhetoric, the paper gives a survey of some common English rhetoric figures found in College English intensive reading, such as metaphor, simile, transferred epithet, allusion, hyperbole, personification, metonymy, antithesis, onomatopoeia, double negative, inversion, rhetoric question, parady, transferred negation, and the like. By elaborating the functions of those rhetoric figures, the paper attempts to enhance the students' rhetoric attainments and arouse their interest in learning English.
\end{abstract}

Keywords: rhetoric attainments, rhetoric figures, College English teaching

\section{Introduction}

Some students often complain that the teaching of College English intensive reading course is so monotonous. It is really the case. How can a tasteless person feel his delicious food? And a certain rhetoric attainment is the prerequisite for the student to enjoy this "delicious food" of College English intensive reading course. The category of rhetoric is quite broad, one of which definitions is given by Aristotle as the art of public speaking by means of persuasion (Aristotle, 1954, pp. 2-12); and Hartwell extends the definition of rhetoric as the art of using words in speaking or writing (Hartwell \& Bentley, 1982, pp. 1-15). That is to say, rhetoric contains both the art of public speaking and the method of composition.

According to Chen Wangdao, a modern Chinese rhetorician, rhetoric includes both active rhetoric and passive rhetoric. The former is characterized as concrete and experiential, which may recall the reader of some concrete image, while the latter is characterized as abstract and conceptual, which is limited to the literal meaning. The active rhetoric entails the figure of speech, which is an expression or word that is used with a metaphorical rather than a literal meaning (Chen, 2006).

Here in this paper the "rhetoric attainment" is limited to the rhetoric knowledge of wording and phrasing, especially, of English figures of speech. In the texts of College English intensive reading course, there exist many common figures of speech, such as metaphor, simile, transferred epithet, allusion, hyperbole, personification, metonymy, antithesis, onomatopoeia, double negative, inversion, rhetoric question, parady, transferred negation, and the like. During the course of teaching, if the students can be enlightened in enjoying the functions of those figures of speech, the course may appeal to them further. Therefore, let us come to appreciate those figures of speech as follows. All the examples are taken from Book 2 and Book 3 of College English Intensive Reading Course (Dong, 2006).

ZHANG Rong-gen, M.A., Associate Professor of Basic Science Education Department, Shanghai Publishing and Printing College, Shanghai, China. 


\section{Appreciations for Figures of Speech}

\section{Metaphor}

A metaphor is a word or phrase used to describe something or something else, in a way that is different from its normal use, in order to show that the two things have the same qualities and to make the description more powerful. Metaphors are used to express a variety of emotions, images, and expressions by combining and comparing to different objects or situation.

E.g.: American education owes a great debt to Thomas Jefferson, who believed that only a nation of educated people could remain free (Book 2 Unit 2).

Here, a free nation is metaphorically borrowed from the category of freedom in philosophy, which means only when human being masters the rule of nature can he really be the owner of the world. Those backward nations may be defeated by other advanced ones, which is known as the law of the jungle.

E.g.: Mothers know instinctively that for children an ounce of praise is worth a pound of scolding (Book 2 Unit 10).

Here the word ounce is metaphorically meant as little, while pound as much. The sentence means that mothers should give their children more praise and less scolding.

E.g.: There were no more butterflies in my stomach when I opened up an abdomen or a chest (Book 2 Unit $6)$.

Here the phrase "butterflies in one’s stomach” metaphorically means one’s nervousness. The sentence tells the readers that with time passing, the surgeon is becoming more and more skillful in the practice and feeling more and more self-confident.

E.g.: And yet, while most of us are only too ready to apply to others the cold wind of criticism, we are somehow reluctant to give our fellows the warm sunshine of praise (Book 2 Unit 10).

Here the cold wind is metaphorically thought of as criticism, while the warm sunshine as praise. People are usually in favor of being praised rather than being criticized; hence the person who is good at praising others is more welcome than the person who is always criticizing others.

E.g.: Shakespeare said, “Our praises are our wages” (Book 2 Unit 10).

Here the word wages are not literally meant as money in material form. Since the housewife is usually not paid by her family for doing the housework, she should at least get her spiritual wage, that is, she should be praised orally by them.

\section{Simile}

A simile is a figure of speech that makes a comparison, showing similarities between two different things. Unlike a metaphor, a simile draws resemblance with the help of the words "like" or "as"1.

E.g.: Yet, when anything went wrong with my car I hastened to him with it, watched him anxiously as he explored its vitals, and listened to his pronouncements as though they were divine oracles—and he always fixed my car (Book 2 Unit 9).

Here the writer compares the mechanic's pronouncements or judgment to divine oracles, meaning that the mechanic always makes a sound judgment in repairing his car, which the writer has to be convinced of.

E.g.: He looked at me with an air of surprised disapproval, as a colonel might look at a private whose

\footnotetext{
${ }^{1}$ https://literarydevices.net/simile/.
} 
bootlaces were undone (Book 2 Unit 3).

Here the writer described himself as a private and the headmaster as a colonel, which shows his embarrassment and depression at the arrogance of the headmaster.

E.g.: Praise is like sunlight to the human spirit; we cannot flower and grow without it (Book 2 Unit 10).

Here praise is compared to sunlight, without which human life and other livings cannot exist.

\section{Transferred Epithet}

A transferred epithet is a little known—but often used-figure of speech where a modifier (usually an adjective) qualifies a noun other than the person or thing it is actually describing. In other words, the modifier or epithet is transferred from the noun it is meant to describe to another noun in the sentence ${ }^{2}$.

E.g.: He looked at me with an air of surprised disapproval, as a colonel might look at a private whose bootlaces were undone (Book 2 Unit 3).

Here the word surprised is a transferred epithet, which actually it should modify the word "he" (the headmaster), meaning that the headmaster was both surprised and dissatisfied at the arrival of the writer, a high school graduate.

\section{Allusion}

An allusion is a brief indirect reference to a person, place, or event-real or fictional. Allusions may be historical, mythological, or literary ${ }^{3}$.

E.g.: Being a teacher is being present at the creation, when the clay begins to breathe (Book 3 Unit 3).

Here the allusion comes from the Biblical story of God's creation of human beings, which suggests the profession of being a teacher is just like that of God. The profession of teaching is so divine and glorious.

E.g.: This was the last straw. I was very young: the prospect of working under a woman constituted the ultimate indignity (Book 2 Unit 3).

Here the phrase "the last straw" comes from an English proverb "It is the last straw which breaks the camel's back".

It means as the final additional small burden that makes the entirety of one's difficulties unbearable, which suggests the writer cannot bear being a teacher at the high school owned by a woman. The reader can clearly see the British man's male chauvinism.

E.g.: Since so often praise is the only wage a housewife receives, surely she of all people should get her measure (Book 2 Unit 10).

The phrase "get her measure" in this sentence entails a set phrase "the lion's share" from Aesop’s Fables, according to which as the king of the forest, the lion gets his biggest share of the prey. Here the writer thinks the housewife should be the most important person of a family.

\section{Hyperbole}

Hyperbole, by definition, is a figure of speech in which exaggeration is used for emphasis or effect as an extravagant statement. ${ }^{4}$

E.g.: "I can live for two months on a good compliment”, said Mark Twain (Book 2 Unit 10).

Here the hyperbolic use suggests a good compliment can make people pleasing and living longer.

\footnotetext{
2 https://www.thoughtco.com.

3 https://www.thoughtco.com.

${ }^{4}$ https://www.thoughtco.com.
} 
E.g.: There is Jacqui, a cleaning woman who knows more by intuition than most of us learn by analysis (Book 3 Unit 3).

Here the hyperbolic use of “a cleaning woman who knows more by intuition” overstates the woman's way of doing manual labor.

E.g.: As I made out a complicated check for a family with several children who had changed their ice-cream order a dozen times, I was ready to quit (Book 2 Unit 10).

Here the hyperbolic use of "a dozen times" emphasizes the writer, as a waitress for the first time, felt so tired with serving the children customers.

\section{Personification}

Personification is a figure of speech in which an inanimate object or abstraction is endowed with human qualities or abilities. $^{5}$

E.g.: The front garden was a gravel square; four evergreen shrubs stood at each corner, where they struggled to survive the dust and fumes from a busy main road (Book 2 Unit 3).

The word survive is usually used to modify human being, whereas here it refers to the inanimate shrubs, highlighting the bad conditions of the school.

E.g.: The villain in the atmosphere is carbon dioxide (Book 2 Unit 5).

Here the inanimate carbon dioxide is personified as a villain, highlighting its bad effects on human beings.

\section{Metonymy}

Metonymy is a figure of speech in which one word or phrase is substituted for another with which it's closely associated ${ }^{6}$.

E.g.: My 15 students read Emerson, Thoreau, and Huxley. They kept diaries. They wrote term papers (Book 3 Unit 3).

Here the metonymical use of the words Emerson, Thoreau, and Huxley, refers to the works of each author, respectively.

E.g.: Were it left to me to decide whether we should have a government without newspapers or newspapers without a government, I should not hesitate a moment to prefer the latter (Book 2 Unit 2).

Here the metonymical use of the phrase "a government without newspapers or newspapers without a government" refers to an autocratic government or a democratic government, respectively.

E.g.: One teacher writes that instead of drowning students' compositions in critical red ink, the teacher will get far more constructive results by finding one or two things which have been done better than last time, and commenting favorably on them (Book 2 Unit 10).

Here the metonymical use of the word red ink refers the critical remarks of the teacher on his students' compositions.

\section{Antithesis}

In rhetoric and grammar, antithesis is the juxtaposition of contrasting ideas in balanced phrases. ${ }^{7}$

E.g.: There is some evidence that dishonesty may ebb and flow (Book 2 Unit 9).

Here the antithesis “ebb and flow” powerfully suggests the writer's attitude toward the students' cheating

\footnotetext{
${ }^{5}$ https://www.thoughtco.com.

${ }^{6}$ https://www.thoughtco.com.

7 https://www.thoughtco.com.
} 
in exams, just like the sea tide ebbing and flowing, a phenomenon sometimes frequent to occur, and sometimes infrequent to happen.

E.g.: Call it conceit—call it self-confidence; whatever it was, I had it (Book 2 Unit 6).

Here the antithesis "Call it conceit—call it self-confidence" vividly shows the increasing self-confidence of a surgeon in his practice.

\section{Onomatopoeia}

Onomatopoeia refers to words that imitate the sounds associated with the objects or actions they refer to ${ }^{8}$.

E.g.: And from that day on, as soon as the table was cleared and the dishes were done, Mother would disappear into her sewing room to practice. The slow tap, tap, tap went on some nights until midnight (Book 3 Unit 5).

Here the onomatopoeic word "tap" vividly describes the hardship of the mother's practice on learning typing.

\section{Double Negative}

A double negative is a nonstandard form using two negatives for emphasis where only one is necessary, and a standard form using two negatives to express a positive ${ }^{9}$.

E.g.: There is no surgical patient I cannot treat competently, treat just as well as or better than any other surgeon... (Book 2 Unit 6).

Here the double negative emphasizes the surgeon's adequate self-confidence about his skills on operations.

E.g.: I'd review all the facts of the case and, not infrequently, wonder if I hadn't made a poor decision (Book 2 Unit 6).

Here the double negative emphasizes the surgeon's inadequate self-confidence about his skills in operating on the patient, and even after the operation he is still feeling dubious about his operation.

\section{Inversion or Anastrophe}

Anastrophe is a rhetorical term for the inversion of conventional word order. It is often used to emphasize one or more of the reversed words.

E.g.: Nor was I afraid of making mistakes (Book 2 Unit 6).

Here the inversion emphasizes the surgeon's adequate self-confidence about his skills on operations: He is always feeling at ease even if he has made mistakes.

E.g.: Distrust can be contagious. But, so can trust! (Book 2 Unit 8)

Here the inversion emphasizes the bad effects of distrusting in the students, which may result in more cheatings in exams, and also the good effects of trusting them which may lead to less cheatings in exams.

E.g.: Nor do I teach because I think I know answers, or because I have knowledge I feel compelled to share (Book 3 Unit 3).

Here the inversion emphasizes the writer's reason for teaching: They are not because he is feeling knowledgeable.

\footnotetext{
${ }^{8}$ https://www.thoughtco.com.

${ }^{9}$ https://www.thoughtco.com.
} 


\section{Rhetoric Question}

The figure of speech known as erotesis is a rhetorical question implying strong affirmation or denial ${ }^{10}$.

E.g.: Honesty: is it going out of style? (Book 2 Unit 8)

Here the rhetoric question implies honesty is not going out of style at all in American schools, so long as the students are being trusted in exams.

\section{Parady}

Parady is a piece of writing intended to amuse by imitating the style of writing used by somebody else.

E.g.: When one thinks of the speed with which spiteful remarks are conveyed, it seems a pity that there isn't more effort to relay pleasing and flattering comments (Book 2 Unit 10).

This sentence may be considered as a parady of a verse by John Milton, "Good news never goes beyond the gate, while bad news spreads far and wide". And in Chinese also there exists such a verse "hăo shì bù chī mén, huài shì chuán qiān lı̀". ${ }^{11}$

\section{Conclusions}

The examples above are only some common figures of speech from College English intensive reading. If rhetoric knowledge concerned is implanted into the students in the lecture, their rhetoric attainments may get enhanced, their appreciation of original English works may also be further improved, and their awareness of English language may even be cultivated. As a result, the "implicit or unexplainable" figures of speech will become explicit for the students to appreciate, and the students' interests in learning English course will be aroused, so much so that the effect of teaching will get improved.

\section{References}

Aristotle. (1954). The rhetoric \& the poetics of Aristotle. (R. Roberts, Trans.). New York: Random.

Chen, W. D. (2006). An introduction to rhetoric. Shanghai: Shanghai Education Press.

Dong, Y. F. (2006). College English intensive reading (3rd ed.). Shanghai: Shanghai Foreign Language Educational Press.

Hartwell, P., \& Bentley, R. H. (1982). Open to language - a new college rhetoric. Oxford: Oxford University Press.

\footnotetext{
${ }^{10}$ https://www.thoughtco.com.

11 https://so.gushiwen.org/mingju/juv_947a535a7c50.aspx.
} 